\begin{tabular}{|l|l|}
\hline SITAS & JAGROS Journal of Agrotechnonogy and Science \\
\hline Jurnal Agroteknologi dan sains \\
Fakultas Pertanian, Universitas Garut \\
P ISSN : 2775-0485, E ISSN : 2548-7752
\end{tabular}

\title{
Pemberian Berbagai Dosis Kompos Tandan Kosong dan Abu Boiler Limbah Kelapa Sawit Terhadap Pertumbuhan dan Hasil Tanaman Kacang Tanah (Arachis hypogaea L.)
}

\section{The Effect of Empty Fruit Bunch Compost and Boiler Ash on Growth and Yield of Peanuts (Arachis hypogaea L.)}

\author{
Silpi Maya Sopa, Resti Fajarfika*, Dadi Nurdiana, Ai Yanti Rismayanti \\ Program Studi Agroteknologi, Fakultas Pertanian Universitas Garut \\ Jl. Raya Samarang No.52A, Tarogong Kaler, Kabupaten Garut, Jawa Barat 44151 \\ e-mail : fajarfikaresti@gmail.com
}

\begin{abstract}
Abstrak
Kacang tanah menyerap unsur hara lebih banyak untuk mendapatkan produksi tinggi. Penelitian ini bertujuan untuk mengetahui pengaruh dosis kompos tandan kosong dan abu boiler limbah kelapa sawit terhadap pertumbuhan dan hasil kacang tanah. Penelitian dilaksanakan pada bulan September sampai November 2019 di lahan Satuan Pelayanan Balai Benih Padi dan Palawija Kecamatan Karangpawitan, Kabupaten Garut, dengan ketinggian 715 meter di atas permukaan laut. Penelitian menggunakan Rancangan Acak Kelompok, dua faktorial dan diulang dua kali. Faktor pertama adalah dosis tandan kosong kelapa sawit $(0,2,4,6$ ton/ha) dan factor kedua adalah dosis abu boiler $(0,1,2,3$ ton/ha). Hasil menunjukkan tidak terjadi interaksi antara dosis tandan kosong kelapa sawit dan abu boiler kelapa sawit terhadap pertumbuhan dan hasil tanaman kacang tanah. Secara mandiri, dosis kompos tandan kosong kelapa sawit 6 ton/ha memberikan pengaruh terbaik terhadap bobot kering tanaman, bobot polong per tanaman, bobot polong basah per plot dan bobot polong kering per plot. Dosis abu boiler kelapa sawit pada 3 ton/ha memberikan pengaruh terbaik terhadap parameter pengamatan tinggi tanaman 45 hari setelah tanam (HST), jumlah daun 45 HST, luas daun, bobot kering tanaman, jumlah polong per tanaman, bobot polong per tanaman, bobot polong basah per plot, jumlah biji per tanaman, bobot polong kering per plot, dan bobot 100 biji.
\end{abstract}

Kata kunci : abu boiler, kacang tanah, kelapa sawit, kompos

\section{Abstract}

Peanuts absorb more nutrients to get high production. This research was aimed to determine the effect of oil palm empty fruit bunch compost and boiler ash dose on growth and yield of peanuts. This research conducted in Rice and Palawija Seed 
Service Unit, Karangpawitan District, Garut Regency at 715 meters above sea level, from September until November 2019. The research used a randomized block design with two factors and two replications. The first factor is the doe oil palm empty fruit bunch (0, 2, 4, 6 ton/ha) and the second factor is dose boiler ash (0, 1, 2, 3 ton/ha). The result showed that no interaction between the dose oil palm empty fruit bunch compost with boiler ash on the growth and yield of peanuts. Independently, the dose of 6 ton/ha oil palm empty fruit compost gives the best effect on crop dry weight, pod weight per plant, wet weight per plot and dry pod weight per plot. Boiler ash dose of 3 ton/ha gives the best effect on plant observation parameters of 45 day after plant height, 45 day after plant of leaf count, leaf area, plant dry weight, number of pods per plant, pod weight per plant, pod weight per plants, dry pod weight per plot, number of seeds per plant, dry pod weight per plot, and weight of 100 seeds.

Key word: Boiler ash, peanut, oil palm, compost

\section{Pendahuluan}

Kacang tanah (Arachis hypogaea (L.) Merr.) merupakan tanaman herba, secara taksonomi termasuk anggota famili Papilionidae, subfamili Leguminosae, genus Arachis (Trustinah, 2015). Kacang tanah termasuk komoditas yang memiliki nilai ekonomi penting dan sebagai sumber protein banyak dimanfaatkan sebagai camilan dalam bentuk direbus atau digoreng, sebagai bumbu pelengkap makanan dan di bidang industri kacang tanah digunakan sebagai bahan-bahan untuk membuat minyak goreng, selai, kue, tepung, biskuit, permen, margarin dan susu. Kacang tanah merupakan bahan makanan yang sehat karena mengandung protein nabati dan lemak yang dibutuhkan manusia, $100 \mathrm{~g}$ kacang tanah mengandung Kalori $525 \mathrm{~g}$, Protein 27,9 g, Karbohidrat 17,4 g, Lemak 42,7 g, Kalsium 3,5 mg, Fosfror 456 mg, Zat besi 5,7 mg, Vitamin B 0,44 mg dan Kadar air 4,0 g (Direktorat Gizi, 2015).

Menurut Kementerian Pertanian Republik Indonesia (2018), produksi nasional kacang tanah tahun 2014 sebesar 638,896 ton biji kering, selanjutnya menurun menjadi 605,449 ton pada tahun 2015, 570,477 ton pada tahun 2016 dan 495,477 ton pada tahun 2017 dan terjadi peningkatan menjadi 512,198 ton pada tahun 2018. Fluktuatif produksi kacang tanah tersebut diduga terjadi karena penurunan luas areal lahan, juga terkendala oleh pengolahan tanah dan pemeliharaan yang belum optimal, serangan hama penyakit, penanaman varietas berproduksi rendah, mutu benih yang rendah serta kekeringan (Tim Bina Karya Tani, 2009).

Tingkat kebutuhan dan pemanfaatan kacang tanah yang semakin meningkat, mengakibatkan kacang tanah perlu untuk lebih dikembangkan dan ditingkatkan produktivitasnya. Pengembangan dan peningkatan produksi kacang tanah salah satunya dapat ditingkatkan dengan cara pengolahan tanah yang aman dan tanpa menggunakan pupuk kimia yaitu dengan menggunakan pupuk kompos yang bahan- 
bahannya mudah didapat dan terbuat dari bahan alam misalnya dari limbah tanaman kelapa sawit (Haryanti et al., 2014).

Indonesia merupakan salah satu negara penghasil minyak kelapa sawit terbesar di dunia (Anggoro dan Budi, 2008). Menurut data Direktorat Jendral Perkebunan, luas perkebunan kelapa sawit (Elaeis guineensis Jacq.) di Indonesia pada tahun 2017 mencapai 14.030.573 ha. Produksi TBS (Tandan Buah Segar) mencapai 37.812.628 ton (Direktorat Jenderal Perkebunan, 2017).

Selain menghasilkan minyak kelapa sawit yang jumlahnya cukup besar disisi lain juga pengolahan kelapa sawit menghasilkan limbah padat dan juga limbah cair. Limbah padat berasal dari proses pengolahan kelapa sawit terdiri dari tandan kosong kelapa sawit, cangkang atau tempurung, serabut, lumpur, abu boiler dan bungkil. Limbah padat yang dihasilkan berbanding lurus dengan jumlah tandan buah segar yang dihasilkan. Limbah padat tandan kosong kelapa sawit merupakan limbah utama yaitu $23 \%$ dari proses pengolahan kelapa sawit. Setiap pengolahan 1 ton tandan buah segar akan dihasilkan tandan kosong kelapa sawit sebanyak 22$23 \%$ atau $220-230 \mathrm{~kg}$. Adapun limbah cair pabrik minyak kelapa sawit (LCPMKS) berasal dari unit pengukusan (sterilisasi) dan klarifikasi (pemisahan produk pabrik kelapa sawit berdasarkan berat jenis) (Rahmadi et al., 2014).

Menurut Hannum et al. (2014) bahwa pencemaran yang ditimbulkan dari industri kelapa sawit dan potensi bahan organik yang terkandung dalam limbah kelapa sawit, menuntut suatu perkebunan kelapa sawit untuk mengelola limbahnya. Langkah tersebut merupakan upaya untuk mengurangi dampak negatif demi mewujudkan industri yang berwawasan lingkungan. Salah satu pemanfaatan yang belum diketahui masyarakat adalah limbah dari pabrik kelapa sawit sebagai pupuk. Hasil samping dari industri perkebunan kelapa sawit seluruhnya dapat dimanfaatkan jika para pelaku industri mampu mengelolanya dengan baik. Tandan kosong kelapa sawit memiliki komposisi kimia berupa selulosa (45,95\%), hemiselulosa $(22,84 \%)$, lignin $(16,49 \%)$, minyak $(2,41 \%)$, dan abu $(1,23 \%)$ (Firmansyah, 2011). Kadar hara kompos tandan kosong kelapa sawit mengandung $0,09 \% \mathrm{Mg}, 51,23 \% \mathrm{C}$-organik, 26,82 \% $\mathrm{C} / \mathrm{N}$ ratio, $1,91 \% \mathrm{~N}$ total, $0,54 \% \mathrm{P}, 1,51 \%$ K, 0,83\% Ca,dan pH 7,13 (Hayat dan Andayani, 2014).

Abu boiler banyak mengandung unsur hara yang sangat bermanfaat dan dapat diaplikasikan pada tanaman sebagai pupuk tambahan atau pengganti pupuk anorganik. Unsur hara yang terkandung dalam abu boiler adalah $\mathrm{N}$ sebesar $0,74 \%$, $\mathrm{P}_{2} \mathrm{O}_{5}$ sebesar $0,84 \%, \mathrm{~K}_{2} \mathrm{O}$ sebesar 2,07\%, Mg sebesar 0,62\% dan juga mengandung senyawa basa-basa yang tinggi dan unsur mikro sehingga dapat meningkatkan $\mathrm{pH}$ tanah (Astianto, 2012). Kandungan tandan kosong dan abu boiler kelapa sawit yang berpotensi sebagai pupuk, inilah yang menjadi daya tarik untuk melakukan penelitian pada tanaman kacang tanah.

Kacang tanah membutuhkan unsur N, Ca, dan K lebih tinggi dibandingkan unsur $\mathrm{P}, \mathrm{Mg}$, dan $\mathrm{S}$. Total serapan $\mathrm{N}, \mathrm{Ca}$, dan $\mathrm{K}$ pada kacang tanah pada tingkat hasil polong 3 ton/ha membutuhkan N sebanyak $192 \mathrm{~kg} / \mathrm{ha}$, Ca sebanyak $77 \mathrm{~kg} / \mathrm{ha}$ 
dan $\mathrm{K}$ sebanyak $66 \mathrm{~kg} / \mathrm{ha}$. Peneliti lain melaporkan bahwa untuk menghasilkan 1,5 ton/ha hingga 2 ton/ha, tanaman kacang tanah menyerap unsur $\mathrm{N}$ sebanyak 108 hingga $125 \mathrm{~kg} / \mathrm{ha}$ (Ismunadji, 1989). Menurut Hafner et al. (1992), total serapan $\mathrm{N}$ pada kondisi pertumbuhan yang baik mencapai $108 \mathrm{~kg} / \mathrm{ha}$. Kandungan $\mathrm{N}$ dalam tajuk tanaman pada fase perkembangan polong dan pengisian biji (umur 60 hari) lebih tinggi dibandingkan $\mathrm{Ca}$ dan $\mathrm{K}$ saat panen. Purwaningsih (2011) melaporkan bahwa kandungan $\mathrm{N}$ pada tajuk lebih tinggi $(3,50-3,86 \%)$ dibandingkan $\mathrm{P}(0,60-$ $0,77 \%)$.

Pada tingkat hasil polong1,6-1,8 ton/ha, kacang tanah menyerap N 97,2-114,4 $\mathrm{kg} / \mathrm{ha}, \mathrm{P} 14,4-17,3 \mathrm{~kg} / \mathrm{ha}, \mathrm{K} 57,8-66,1 \mathrm{~kg} / \mathrm{ha}, \mathrm{S} 12,2-13,7 \mathrm{~kg} / \mathrm{ha}$, Ca44,2-51,5

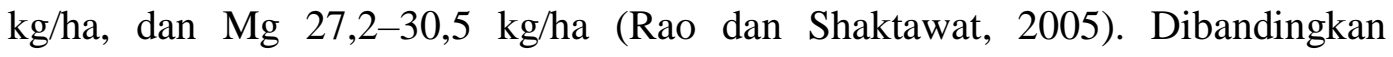
komoditas tanaman pangan lainnya, kacang tanah menyerap unsur Ca paling tinggi, untuk menghasilkan satu ton biji tanaman kacang tanah menyerap $11-22 \mathrm{~kg} \mathrm{Ca}$ (Meena et al., 2007).

Kebutuhan yang tinggi akan unsur hara N, K, Ca serta unsur hara lainnya dapat terpenuhi dari pemberian pupuk kompos tandan kosong kelapa sawit maupun abu boiler. Informasi tentang tingkat dosis pupuk kompos tandan kosong kelapa sawit dan abu boiler masih perlu dikembangkan. Oleh karena itu, penelitian ini penting dilakukan khususnya pada tanaman kacang tanah.

\section{Metodologi}

Penelitian ini dilaksanakan pada bulan September sampai November 2019 di lahan Satuan Pelayanan Balai Benih Padi dan Palawija Kecamatan Karangpawitan, Kabupaten Garut, dengan ketinggian 715 meter diatas permukaan laut (m dpl). Bahan yang digunakan yaitu benih kacang tanah varietas zebra, kompos tandan kosong dan abu boiler kelapa sawit. Alat yang digunakan yaitu cangkul, timbangan, papan nama, kamera dan alat tulis.

Penelitian menggunakan Rancangan Acak Kelompok (RAK) pola faktorial $4 \times$ 4 yang di ulang sebanyak dua kali. Faktor pertama adalah dosis tandan kosong kelapa sawit (T) yang terdiri dari empat taraf, yaitu: $\mathrm{t}_{0}: 0$ ton/ha (kontrol) , $\mathrm{t}_{1}: 2$ ton/ha $(0.4 \mathrm{~kg} / \mathrm{plot}), \mathrm{t}_{2}: 4 \mathrm{ton} / \mathrm{ha}(0,8 \mathrm{~kg} / \mathrm{plot}), \mathrm{t}_{3}: 6$ ton/ha $(1,2 \mathrm{~kg} / \mathrm{plot})$. Faktor $\mathrm{ke}$ dua adalah dosis abu boiler kelapa sawit (B) yang terdiri dari empat taraf, yaitu: $\mathrm{b}_{0}$ : 0 ton/ ha (kontrol), $b_{1}: 1$ ton/ha $(0,2 \mathrm{~kg} / \mathrm{plot}), \mathrm{b}_{2}: 2$ ton/ha $(0.4 \mathrm{~kg} / \mathrm{plot}), \mathrm{b}_{3}: 3$ ton $/$ ha $(0,6 \mathrm{~kg} / \mathrm{plot})$. Terdapat 16 kombinasi taraf perlakuan percobaan, sehingga terdapat 32 plot. Setiap plot percobaan terdiri dari 20 tanaman sehingga total keseluruhan adalah 640 tanaman.

Kompos tandan kosong kelapa sawit dibuat dengan cara mencacah tandan kosong $(5 \mathrm{~cm})$ sebanyak $20 \mathrm{~kg}$, ditambahkan dedak $(2 \mathrm{~kg})$ dan air yang telah dicampur dengan gula tebu (200 ml) dan EM4 (20 ml), selanjutnya dituutup menggunakan terpal dan diinkubasi selama 6-12 minggu. Kompos tandan kosong kelapa sawit di aplikasikan 1 minggu sebelum tanam pemberiannya dilakukan 
dengan cara memasukan dan mencampurkan tandan kosong kelapa sawit ke dalam tanah sesuai dosis perlakuan, sedangkan abu boiler di aplikasikan pada saat tanam dan 4 minggu setelah tanam pada saat tanaman kacang tanah mulai berbunga pemberiannya sesuai dosis perlakuan.

\section{Hasil dan Pembahasan}

\section{Tinggi tanaman $(\mathbf{c m})$}

Hasil analisis ragam menunjukkan tidak terjadi interaksi antara dosis kompos tandan kosong dan dosis abu boiler kelapa sawit terhadap rata-rata tinggi tanaman pada umur pengamatan 15, 30, dan 45 HST. Hal tersebut diduga karena faktor pupuk organik dengan kandungan unsur hara tinggi yang paling berpengaruh pada pertumbuhan tanaman.

Secara mandiri kompos tandan kosong berpengaruh terhadap tinggi tanaman dengan hasil tertinggi terdapat pada perlakuan $t_{2}$ dan $t_{3}$ pada umur 15, 30, dan 45 HST. Hal tersebut diduga karena dosis $t_{2}$ dan $t_{3}$ mampu memberikan kebutuhan unsur yang lebih baik dibanding taraf perlakuan yang lainnya. Hasil ini mendekati hasil penelitian Reza et al. (2017) yang menunjukkan hasil berbeda nyata pada tinggi tanaman kacang hijau pada perlakuan 5 ton/ha kompos tandan kosong kelapa sawit. Penelitian ini tidak dilakukan pemupukan kimia sehingga tanaman hanya memenuhi kebutuhan unsur hara dari pupuk kompos tandan kosong kelapa sawit. Perlakuan $t_{0}$ dan $t_{1}$ menyebabkan tidak berbeda nyata diduga karena unsur hara sangat sedikit.

Tabel 1. Pengaruh kompos tandan kosong dan abu boiler terhadap tinggi tanaman

\begin{tabular}{lccc}
\hline \multirow{2}{*}{ Perlakuan } & \multicolumn{3}{c}{ Waktu pengamatan } \\
\cline { 2 - 4 } & $15 \mathrm{HST}$ & $30 \mathrm{HST}$ & $45 \mathrm{HST}$ \\
\hline Kompos tandan kosong (ton/ha) & & \\
$\mathrm{t}_{0}: 0$ & $7,13 \mathrm{a}$ & $10,46 \mathrm{a}$ & $12,41 \mathrm{a}$ \\
$\mathrm{t}_{1}: 2$ & $7,49 \mathrm{ab}$ & $12,00 \mathrm{ab}$ & $13,64 \mathrm{a}$ \\
$\mathrm{t}_{2}: 4$ & $7,96 \mathrm{~b}$ & $12,77 \mathrm{~b}$ & $15,40 \mathrm{~b}$ \\
$\mathrm{t}_{3}: 6$ & $8,06 \mathrm{~b}$ & $13,43 \mathrm{~b}$ & $15,87 \mathrm{~b}$ \\
Abu boiler (ton/ha) & & & \\
$\mathrm{b}_{0}: 0$ & $7,83 \mathrm{a}$ & $11,31 \mathrm{a}$ & $13,71 \mathrm{ab}$ \\
$\mathrm{b}_{1}: 1$ & $7,76 \mathrm{a}$ & $12,30 \mathrm{a}$ & $13,50 \mathrm{a}$ \\
$\mathrm{b}_{2}: 2$ & $7,56 \mathrm{a}$ & $12,60 \mathrm{a}$ & $14,95 \mathrm{ab}$ \\
$\mathrm{b}_{3}: 3$ & $7,49 \mathrm{a}$ & $12,46 \mathrm{a}$ & $15,16 \mathrm{~b}$ \\
\hline
\end{tabular}

Keterangan : Angka rata-rata pada setiap kolom yang ditandai dengan huruf yang sama menunjukkan tidak berbeda nyata menurut Uji Jarak Berganda Duncan pada taraf $5 \%$. 
Hasil analisis ragam perlakuan abu boiler terhadap tinggi tanaman pada umur 15 dan 30 HST tidak berbeda nyata sedangkan pada umur 45 HST menunjukan berbeda nyata. Dosis abu boiler pada 3 ton/ha menjadi perlakuan terbaik diduga akibat dari peningkatan $\mathrm{pH}$ tanah yang menyebabkan serapan unsur hara menjadi lebih tersedia bagi tanaman salah satunya unsur N. Umur 15 dan 30 HST tidak terpengaruh oleh perlakuan. Hal tersebut diduga karena kebutuhan unsur hara pada umur 15 dan 30 HST masih sedikit sehingga kebutuhan unsur harannya tercukupi pada semua taraf perlakuan, berbeda dengan kebutuhan unsur hara pada 45 HST yang mulai membutuhkan unsur hara yang cukup banyak sehingga perbedaan perlakuan menyebabkan perbedaan yang berbeda nyata.

Rentang pH ideal untuk tanaman berkisar 5,5 - 6,5. Nilai pH dibawah masam menyebabkan kelarutan asam fosfat, nitrogen kalsium, dan magnesium sedikit atau kurang tersedia akibat terikat dengan unsur lain (Hendra dan Andoko, 2014). Menurut Resh (2013) kebanyakan tanaman menginginkan $\mathrm{pH}$ dalam rentang antara 5,8 -6,5 karena $\mathrm{pH}$ sangat mempengaruhi kemampuan tanaman dalam menyerap unsur hara. Selain $\mathrm{pH}$ unsur hara $\mathrm{N}$ pun menjadi lebih tingi akibat penambahan diperlakuan. Menurut Lingga (1994), unsur N dapat meningkatkan pertumbuhan tanaman seperti tinggi tanaman, karena $\mathrm{N}$ berperan dalam pembentukan asam amino dan juga pembentukan klorofil.

Pola serapan hara tanaman kacang tanah dalam satu musim tanam mengikuti pola akumulasi bahan kering (Halevy dan Hartzook,1988). Laju produksi bahan kering sangat lambat hingga fase pembungaan, dan meningkat cepat pada fase reproduktif dan pemasakan polong. Sebanyak 10-19\% unsur hara N, P, K, Ca, dan $\mathrm{Mg}$ diserap selama fase vegetatif, sedangkan sisanya diserap selama fase reproduktif dan pemasakan polong. Pola serapan hara juga dipengaruhi oleh musim, dimana serapan pada musim hujan lebih tinggi dibandingkan pada musim kemarau. Kandungan unsur hara N, P, K, dan Ca dalam tajuk pada musim kemarau berturutturut adalah 104,2 mg N, 6,93 mg P, 128,19 mg K dan 119,6 mg Ca per tanaman, sedangkan pada musim hujan adalah 174,07 mg N, 14,36 mg P, 203,11 mg K, dan 190,01 mg Ca per tanaman (Junjittakarna et al., 2013).

\section{Luas Daun $\left(\mathbf{c m}^{2}\right)$}

Hasil analisis ragam menunjukkan tidak terjadi interaksi antara berbagai dosis kompos tandan kosong dan dosis abu boiler kelapa sawit terhadap rata-rata luas daun pada umur pengamatan $45 \mathrm{HST}$. Hal tersebut diduga karena faktor pupuk organik dengan kandungan unsur hara tinggi yang paling berpengaruh pada pertumbuhan tanaman.

Secara mandiri hasil analisis ragam kompos tandan kosong kelapa sawit terhadap luas daun menunjukkan hasil berbeda nyata pada taraf perlakuan $\mathrm{t}_{0}, \mathrm{t}_{1}$, dan $\mathrm{t}_{2}$ dibandingkan $\mathrm{t}_{3}$. Hal tersebut diduga karena pemberian dosis 6 ton/ha menjadi perlakuan terbaik karena mampu memberikan kecukupan unsur hara bagi 
pembentukan jaringan pada daun sehingga luas daun menjadi lebih tinggi dibanding taraf perlakuan lainnya. Luas daun erat kaitannya dengan pertumbuhan vegetatif.

Tabel 2. Hasil Analisis Luas Daun $\left(\mathrm{cm}^{2}\right)$

\begin{tabular}{lc}
\multicolumn{1}{c}{ Perlakuan } & Luas Daun $\left(\mathrm{cm}^{2}\right)$ \\
\hline Kompos tandan kosong (ton/ha) & \\
$\mathrm{t}_{0}: 0$ & $21,89 \mathrm{a}$ \\
$\mathrm{t}_{1}: 2$ & $29,58 \mathrm{ab}$ \\
$\mathrm{t}_{2}: 4$ & $34,21 \mathrm{ab}$ \\
$\mathrm{t}_{3}: 6$ & $39,92 \mathrm{~b}$ \\
\hline Abu boiler (ton/ha) & \\
$\mathrm{b}_{0}: 0$ & $27,60 \mathrm{a}$ \\
$\mathrm{b}_{1}: 1$ & $31,10 \mathrm{ab}$ \\
$\mathrm{b}_{2}: 2$ & $24,78 \mathrm{a}$ \\
$\mathrm{b}_{3}: 3$ & $42,12 \mathrm{~b}$ \\
\hline $\mathrm{K}: 3$ &
\end{tabular}

Keterangan : Angka rata-rata pada setiap kolom yang ditandai dengan huruf yang sama menunjukkan tidak berbeda nyata menurut Uji Jarak Berganda Duncan pada taraf $5 \%$.

Pertumbuhan vegetatif tanaman sangat ditunjang oleh pupuk $\mathrm{N}$ tersedia yang dikandung di tanah. Hal tersebut diduga karena pupuk $\mathrm{N}$ yang diperlukan tercukupi oleh hasil penambahan kompos pada 3 ton/ha. Hasil penelitian Syafril dan Andayani (2014) dosis pupuk tandan kosong kelapa sawit 5 ton per hektar mampu meningkatkan kadungan klrofil pada daun. Sejalan dengan hasil penelitian Hatta et al. (2014) aplikasi dosis pupuk tandan kosong kelapa sawit 6 ton/ha mampu meningkatkan pertumbuhan dan hasil tanaman jagung organik.

Hasil analisis ragam abu boiler terhadap luas daun menunjukkan taraf perlakuan $b_{0}, b_{1}$, dan $b_{2}$ tidak berbeda nyata, namun ketiganya berbeda nyata dibandingkan taraf perlakuan $b_{3}$. Hal tersebut diduga karena taraf perlakuan 3 ton/ha menjadi taraf perlakuan terbaik karena mampu menyediakan unsur hara yang lebih tinggi dibandingkan taraf perlakuan yang lainnya, hal ini sejalan dengan analisis ragam jumlah daun. Hal tersebut diduga karena kandungan nitrogen pada abu boiler menjadi bahan pemacu pertumbuhan yang lebih tinggi bagi luasnya daun tanaman. Pupuk nitrogen mampu menyuplai unsur hara untuk pertumbuhan vegetatif seperti tinggi tanaman, jumlah daun, dan pertumbuhan diameter batang (Wiekandyne, 2012).

\section{Jumlah Daun (helai)}

Hasil analisis ragam menunjukkan tidak terjadi interaksi antara berbagai dosis tandan kosong dan dosis abu boiler kelapa sawit terhadap rata-rata jumlah daun pada umur pengamatan 15, 30, dan 45 HST. Hal tersebut diduga karena faktor pupuk organik dengan kandungan unsur hara tinggi yang paling berpengaruh pada pertumbuhan tanaman. 
Tabel 3. Hasil Analisis Jumlah Daun (helai)

\begin{tabular}{lccc}
\multicolumn{1}{c}{ Per lakuan } & \multicolumn{3}{c}{ Waktu pengamatan } \\
\hline & $15 \mathrm{HST}$ & $30 \mathrm{HST}$ & $45 \mathrm{HST}$ \\
\hline Kompos tandan kosong (ton/ha) & & & \\
$\mathrm{t}_{0}: 0$ & $17,60 \mathrm{a}$ & $33,65 \mathrm{a}$ & $72,19 \mathrm{a}$ \\
$\mathrm{t}_{1}: 2$ & $18,44 \mathrm{a}$ & $41,00 \mathrm{a}$ & $82,26 \mathrm{ab}$ \\
$\mathrm{t}_{2}: 4$ & $21,33 \mathrm{ab}$ & $51,92 \mathrm{~b}$ & $92,99 \mathrm{~b}$ \\
$\mathrm{t}_{3}: 6$ & $23,10 \mathrm{~b}$ & $52,21 \mathrm{~b}$ & $95,75 \mathrm{~b}$ \\
Abu boiler (ton/ha) & & & \\
$\mathrm{b}_{0}: 0$ & $21,63 \mathrm{a}$ & $40,90 \mathrm{a}$ & $81,59 \mathrm{a}$ \\
$\mathrm{b}_{1}: 1$ & $20,02 \mathrm{a}$ & $44,50 \mathrm{a}$ & $75,21 \mathrm{a}$ \\
$\mathrm{b}_{2}: 2$ & $19,22 \mathrm{a}$ & $46,53 \mathrm{a}$ & $83,97 \mathrm{a}$ \\
$\mathrm{b}_{3}: 3$ & $19,61 \mathrm{a}$ & $46,85 \mathrm{a}$ & $102,43 \mathrm{~b}$ \\
\hline
\end{tabular}

Keterangan : Angka rata-rata pada setiap kolom yang ditandai dengan huruf yang sama menunjukkan tidak berbeda nyata menurut Uji Jarak Berganda Duncan pada taraf $5 \%$.

Hasil analisis ragam kompostandan kosong kelapa sawit terhadap jumlah daun menunjukkan taraf perlakuan $\mathrm{t}_{0}$ dan $\mathrm{t}_{1}$ tidak berbeda nyata, namun keduanya berbeda nyata dibandingkan taraf perlakuan $t_{2}$ dan $t_{3}$. Hal ini sejalan dengan hasil analisis tinggi tanaman, diduga taraf perlakuan 4 dan 6 ton/ha menjadi perlakuan terbaik akibat dari peningkatan jumlah unsur hara yang mampu dimanfaatkan oleh tanaman dari tanah.

Darnoko et al. (1993) menyatakan bahwa bahan organik tandan kosong kelapa sawit yang terurai secara sempurna akibat dari perombakan senyawa - senyawa kompleks oleh mikroorganisme akan menghasilkan sejumlah unsur hara yang penting seperti N, P, K. Tersedianya unsur hara yang dibutuhkan akan mampu meningkatkan pertumbuhan dan produksi tanaman itu sendiri. Unsur hara hasil rombakan mikroorganisme tersebut salah satunya berupa nitrogen yang diperlukan tanaman untuk merangsang pertumbuhan tanaman terutama batang, cabang, dan daun (Harjadi, 1996). Menurut Wiekandyne (2012) bahwa pemberian pupuk nitrogen mampu menyuplai unsur hara untuk pertumbuhan vegetatif seperti tinggi tanaman dan jumlah daun.

Hasil analisis ragam abu boiler terhadap jumlah daun terlihat tidak berbeda nyata pada stadia umur 15 dan 30 HST. Hal tersebut diduga karena akibat dari pemberian abu boiler dilakukan pada umur 30 HST sehingga baru bisa terlihat pada umur $45 \mathrm{HST}$. Hasil analisis ragam $45 \mathrm{HST}$ terlihat berbeda nyata pada taraf perlakuan $b_{0}, b_{1}$ dan $b_{2}$ dibandingkan taraf perlakuan $b_{3}$. Hal tersebut diduga karena pada 3 ton/ha menjadi perlakuan terbaik karena unsur hara yang dibutuhkan dalam pembentukan jumlah daun lebih tersedia dalam dosis yang lebih tinggi dibanding taraf perlakuan yang lainnya. Lingga dan Marsono (2003) menyatakan unsur N sangat penting untuk pertumbuhan vegetatif tanaman karena dapat merangsang pertumbuhan secara keseluruhan, khususnya batang, cabang dan daun. 


\section{Bobot Kering per Tanaman (g)}

Hasil analisis ragam menunjukkan tidak terjadi interaksi antara berbagai dosis tandan kosong dan abu boiler kelapa sawit terhadap rata-rata bobot kering tanaman pada umur pengamatan 45 HST. Hal tersebut diduga karena faktor pupuk organik dengan kandungan unsur hara tinggi yang paling berpengaruh pada pertumbuhan tanaman.

Tabel 4. Hasil Analisis Bobot Kering Tanaman (g)

\begin{tabular}{lc}
\hline \multicolumn{1}{c}{ Perlakuan } & Bobot Kering Tanaman $(\mathrm{g})$ \\
\hline Tandan kosong kelapa sawit & \\
$\mathrm{t}_{0}: 0$ & $2,14 \mathrm{a}$ \\
$\mathrm{t}_{1}: 2$ & $2,61 \mathrm{a}$ \\
$\mathrm{t}_{2}: 4$ & $2,66 \mathrm{a}$ \\
$\mathrm{t}_{3}: 6$ & $4,26 \mathrm{~b}$ \\
Abu boiler (ton/ha) & \\
$\mathrm{b}_{0}: 0$ & $2,44 \mathrm{a}$ \\
$\mathrm{b}_{1}: 1$ & $2,80 \mathrm{a}$ \\
$\mathrm{b}_{2}: 2$ & $2,97 \mathrm{ab}$ \\
$\mathrm{b}_{3}: 3$ & $3,47 \mathrm{~b}$ \\
\hline
\end{tabular}

Keterangan : Angka rata-rata pada setiap kolom yang ditandai dengan huruf yang sama menunjukkan tidak berbeda nyata menurut Uji Jarak BergandaDuncan pada taraf $5 \%$.

Hasil analisis ragam kompos tandan kosong kelapa sawit terhadap bobot kering per tanaman menunjukkant $t_{0}, t_{1}$, dan $t_{3}$ tidak terbeda nyata tetapi tidak berbeda nyata dengan $t_{3}$. Hal tersebut karena taraf perlakuan 6 ton/ha menjadi perlakuan terbaik diduga karena mampu mengikat jumlah $\mathrm{CO}_{2}$ diudara lebih baik dibanding taraf perlakuan yang lainnya.

Pengikatan $\mathrm{CO}_{2}$ di udara tidak terlepas dari proses fotosintesis yang terjadi di daun dan berhubungan erat dengan luas daun. Sejalan dengan hasil analisis luas daun taraf perlakuan $t_{3}$ memiliki luas daun yang berbeda nyata. Produksi bahan kering tanaman tergantung dari penerimaan penyinaran matahari dan pengambilan karbon dioksida dan air dalam tumbuhan. Penampakan dan laju perkembangan suatu tanaman tergantung faktor-faktor iklim seperti suhu, panjang hari dan persediaan air (Sudaryani dan Sugiharti, 1990).

Hasil analisis ragam abu boiler terhadap bobot kering per tanaman menunjukkan perlakuan $b_{0}, b_{1}, b_{2}$ tidak berbeda nyata tetapi berbeda nyata dengan $b_{2}$ perlakuan $b_{2}$ tidak berbeda nyata dengan semua perlakuan. Dosis pada taraf perlakuan 3 ton/ha memperoleh hasil tertinggi terhadap bobot kering tanaman hal tersebut diduga karena luas daun yang lebih banyak mampu mengikat $\mathrm{CO}_{2}$ dan pemanfaatan sinar matahari lebih tinggi dibanding luas daun yang lebih sempit. Radiasi sinar matahari dapat memberikan efek tertentu pada tumbuhan bila cahaya tersebut diabsorbsi.Secara fisiologis cahaya mempunyai pengaruh baik langsung maupun tidak langsung.Pengaruh secara langsung melalui fotosintesis dan secara tidak langsung melalui pertumbuhan dan perkembangan tanaman akibat respon metabolik yang langsung (Fitter dan Hay, 1991). 


\section{Jumlah Polong per Tanaman}

Hasil analisis ragam menunjukkan tidak terjadi interaksi antara berbagai dosis tandan kosong kelapa sawitdan dosis abu boiler kelapa sawit terhadap rata-rata jumlah polong per tanaman. Hal tersebut diduga karena faktor pupuk organik dengan kandungan unsur hara tinggi yang paling berpengaruh pada pertumbuhan tanaman.

Tabel 5. Hasil Analisis Jumlah Polong per Tanaman (buah)

\begin{tabular}{lc}
\hline \multicolumn{1}{c}{ Perlakuan } & Jumlah Polong per Tanaman (buah) \\
\hline Tandan kosong kelapa sawit (ton/ha) & $14,87 \mathrm{a}$ \\
$\mathrm{t}_{0}: 0$ & $15,49 \mathrm{a}$ \\
$\mathrm{t}_{1}: 2$ & $16,64 \mathrm{ab}$ \\
$\mathrm{t}_{2}: 4$ & $18,22 \mathrm{~b}$ \\
$\mathrm{t}_{3}: 6$ & \\
Abu boiler (ton/ha) & $14,28 \mathrm{a}$ \\
$\mathrm{b}_{0}: 0$ & $15,10 \mathrm{a}$ \\
$\mathrm{b}_{1}: 1$ & $15,72 \mathrm{a}$ \\
$\mathrm{b}_{2}: 2$ & $20,11 \mathrm{~b}$ \\
$\mathrm{~b}_{3}: 3$ & \\
\hline
\end{tabular}

Keterangan : Angka rata-rata pada setiap kolom yang ditandai dengan huruf yang sama menunjukkan tidak berbeda nyata menurut Uji Jarak Berganda Duncan pada taraf $5 \%$.

Hasil analisis ragam kompos tandan kosong kelapa sawit terhadap jumlah polong per tanaman menunjukkan berbeda nyata pada taraf perlakuan $\mathrm{t}_{0}, \mathrm{t}_{1}$, dan $\mathrm{t}_{2}$ dibandingkan taraf perlakuan $\mathrm{t}_{3}$. Hal tersebut diduga karena taraf perlakuan 6 ton/ha mampu memberikan kandungan hara yang lebih baik, namun selain itu kandungan kompos yang tinggi memberikan efek lebih baik bagi tanah sehingga pembentukan polong menjadi lebih mudah sehingga hasil polong menjadi lebih tinggi.

Bahan organik yang terkandung dalam kompos tandan kosong kelapa sawit berperan sebagai bahan pembenah tanah yang dapat meningkatkan kemampuan tanah untuk menahan air dan meningkatkan aktivitas mikroorganisme di dalam tanah, dengan demikian ketersediaan hara baik makro maupun hara mikro di dalam tanah juga akan meningkat. Pernyataan ini sesuai dengan pendapat Puguh et al. (2011) bahwa ketersediaan unsur hara yang dapat diserap oleh tanaman merupakan salah satu faktor yang mempengaruhi pertumbuhan tanaman.

Hasil analisis ragam abu boiler terhadap jumlah polong per tanaman menunjukkan berbeda nyata pada taraf perlakuan $b_{0}, b_{1}$, dan $b_{2}$ dibanding taraf perlakuan $b_{3}$. Taraf 3 ton/ha memiliki nilai rata-rata terbaik diduga karena mampu meningkatkan $\mathrm{pH}$ dan menambah unsur hara sehingga pertumbuhan polong menjadi lebih banyak. Kemasaman $(\mathrm{pH})$ tanah yang cocok untuk kacang tanah adalah 6,5-7,0. Tanaman masih cukup baik bila tumbuh pada tanah agak masam ( $\mathrm{pH} 5,0-5,5)$ namun tidak sebaik $\mathrm{pH}$ 6,5-7, tetapi peka terhadap tanah basa $(\mathrm{pH}>7)$. Pada $\mathrm{pH}$ tanah 7,5-8,5 (bereaksi basa) daun akan menguning dan terjadi bercak hitam pada polong. Di tanah basa, hasil polong akan berkurang karena ukuran polong dan jumlah polong menurun (Agustina dan Purnomo, 2018). 


\section{Bobot Polong per Tanaman (g)}

Hasil analisis ragam menunjukkan tidak terjadi interaksi antara berbagai dosis tandan kosong kelapa sawitdan dosis abu boiler kelapa sawit terhadap rata-rata bobot polong per tanaman. Hal tersebut diduga karena faktor pupuk organik dengan kandungan unsur hara tinggi yang paling berpengaruh pada pertumbuhan tanaman.

Tabel 6. Hasil Analisis Bobot Polong per Tanaman

\begin{tabular}{lc}
\hline \multicolumn{1}{c}{ Perlakuan } & Bobot Polong per Tanaman $(\mathrm{g})$ \\
\hline Tandan kosong kelapa sawit (ton/ha) & \\
$\mathrm{t}_{0}: 0$ & $61,64 \mathrm{a}$ \\
$\mathrm{t}_{1}: 2$ & $65,51 \mathrm{a}$ \\
$\mathrm{t}_{2}: 4$ & $67,91 \mathrm{a}$ \\
$\mathrm{t}_{3}: 6$ & $75,48 \mathrm{~b}$ \\
Abu boiler (ton/ha) & \\
$\mathrm{b}_{0}: 0$ & $61,12 \mathrm{a}$ \\
$\mathrm{b}_{1}: 1$ & $65,49 \mathrm{a}$ \\
$\mathrm{b}_{2}: 2$ & $66,97 \mathrm{a}$ \\
$\mathrm{b}_{3}: 3$ & $76,95 \mathrm{~b}$ \\
\hline
\end{tabular}

Keterangan : Angka rata-rata pada setiap kolom yang ditandai dengan huruf yang sama menunjukkan tidak berbeda nyata menurut Uji Jarak Berganda Duncan pada taraf $5 \%$.

Hasil analisis ragam kompos tandan kosong kelapa sawit terhadap bobot polong per tanaman menunjukkan berbeda nyata pada taraf perlakuan $\mathrm{t}_{0}, \mathrm{t}_{1}$, dan $\mathrm{t}_{2}$ dibanding taraf perlakuan $\mathrm{t}_{3}$. Hal ini sejalan dengan analisis ragam jumlah polong dan jumlah biji pertanaman. Taraf perlakuan 6 ton/ha menjadi dosis terbaik diduga akibat dari hasil fotosintat yang dihasilkan lebih banyak sehingga unsur hara yang diserap oleh tanaman menjadi lebih banyak. Faktor lain yang menjadi penunjang adalah struktur tanah yang lebih remah dan gembur, hal ini menjadikan keuntungan bagi pertumbuhan polong sehingga mampu tumbuh dan berkembang lebih tinggi dibanding taraf yang lainnya.

Hasil analisis ragam abu boiler terhadap bobot polong per tanaman menunjukkan berbeda nyata pada taraf perlakuan $b_{0}, b_{1}$, dan $b_{2}$ dibanding taraf perlakuan $b_{3}$. Hal terssebut diduga karena hasil fotosintat tanaman pada perlakuan 3 ton/ha lebih banyak karena serapan unsur hara lebih tinggi akibat $\mathrm{pH}$ yang lebih baik dan kandungan unsur hara yang jauh lebih tinggi yang bisa dimanfaatkan bagi proses fotosintesis tanaman, sehingga taraf perlakuan $b_{3}$ menjadi perlakuan terbaik dalam menghasilkan bobot polong tanaman. Pada percobaan di rumah kaca menggunakan $\mathrm{N}$ isotop, diketahui bahwa $60-65 \%$ dari $\mathrm{N}$ yang diberikan diserap melalui akar dan 35-40\% diserap melalui kulit polong (Inanaga et al., 1990).

\section{Bobot Polong Basah per Plot (g)}

Hasil analisis ragam menunjukkan tidak terjadi interaksi antara berbagai dosis tandan kosong dan abu boiler kelapa sawit terhadap rata-rata bobot polong basah per plot. Hal tersebut diduga karena faktor pupuk organik dengan kandungan unsur hara tinggi yang paling berpengaruh pada pertumbuhan tanaman.

Hasil analisis ragam kompos tandan kosong kelapa sawit terhadap bobot polong basah per plot menunjukkan berbeda nyata pada taraf perlakuan $\mathrm{t}_{0}, \mathrm{t}_{1}$, dan $\mathrm{t}_{2}$ 
dibandingkan taraf perlakuan $\mathrm{t}_{3}$. Hal ini sejalan dengan analisis ragam jumlah polong dan jumlah biji pertanaman yang menunjukkan bahwa taraf perlakuan 6 ton/ha menjadi taraf perlakuan terbaik. Hal tersebut diduga karena struktur tanah yang lebih remah dan gembur juga unsur hara yang lebih banyak membantu tumbuh dan berkembang lebih tinggi bagi tanaman sehingga mempengaruhi penyaluran jumlah asimilat kedalam biji kacang.

Tabel 7. Hasil Analisis Bobot Polong Basah per Plot (g)

\begin{tabular}{lc}
\multicolumn{1}{c}{ Perlakuan } & Bobot Polong Basah per Plot $(\mathrm{g})$ \\
\hline Tandan kosong kelapa sawit \\
(ton/ha) \\
$\mathrm{t}_{0}: 0$ & $724,38 \mathrm{a}$ \\
$\mathrm{t}_{1}: 2$ & $727,13 \mathrm{a}$ \\
$\mathrm{t}_{2}: 3$ & $789,55 \mathrm{a}$ \\
$\mathrm{t}_{3}: 4$ & $917,21 \mathrm{~b}$ \\
Abu boiler (ton/ha) & \\
$\mathrm{b}_{0}: 0$ & $750,52 \mathrm{a}$ \\
$\mathrm{b}_{1}: 1$ & $763,27 \mathrm{a}$ \\
$\mathrm{b}_{2}: 2$ & $774,20 \mathrm{a}$ \\
$\mathrm{b}_{3}: 3$ & $870,28 \mathrm{~b}$ \\
\hline
\end{tabular}

Keterangan : Angka rata-rata pada setiap kolom yang ditandai dengan huruf yang sama menunjukkan tidak berbeda nyata menurut Uji Jarak Berganda Duncan pada taraf $5 \%$.

Tersedianya unsur hara yang cukup dalam tanah akan berdampak pada optimalnya aktivitas fisiologi dan metabolisme suatu tanaman, salah satunya yaitu kemampuan tanaman untuk mentranslokasikan asimilat ke dalam biji. Kamil (1997) menyatakan bahwa peningkatan berat biji pada tanaman bergantung pada tersedianya asimilat dan kemampuan tanaman itu untuk mentranslokasikannya pada biji.

Hasil analisis ragam abu boiler terhadap bobot polong basah per plot menunjukkan berbeda nyata pada taraf perlakuan $b_{0}, b_{1}$, dan $b_{2}$ dibanding taraf perlakuan $b_{3}$. Peningkatan jumlah unsur hara yang terserap pada perlakuan $b_{3}$ mampu meningkatkan bobot polong perplot. Sutedjo (2006) menyatakan bahwa salah satu peranan fosfor untuk tanaman adalah dapat meningkatkan produksi bijibijian. Sementara itu, unsur K yang terkandung dalam kompos juga berperan dalam proses translokasi bahan-bahan organik dari source ke sink dalam proses pengisian biji. Menurut Mengel dan Kirby (1987) peranan K sangat penting dalam proses fotosintesis, yakni sebagai aktivator enzim pada translokasi fotosintat.

\section{Bobot Polong Kering per Plot (g)}

Hasil analisis ragam menunjukkan tidak terjadi interaksi antara berbagai dosis tandan kosong dan abu boiler kelapa sawit terhadap rata-rata bobot polong kering per plot. Hal tersebut diduga karena faktor pupuk organik dengan kandungan unsur hara tinggi yang paling berpengaruh pada pertumbuhan tanaman.

Hasil analisis ragam kompos tandan kosong kelapa sawit terhadap bobot polong kering per plot menunjukkan berbeda nyata pada taraf perlakuan $\mathrm{t}_{0}, \mathrm{t}_{1}$, dan $t_{2}$ dibandingkan taraf perlakuan $t_{3}$. Hal ini sejalan dengan bobot basah polong per 
plot. Hardjowigeno (2004) menyatakan bahwa bahan organik akan memperbaiki struktur tanah sehingga ketersediaan unsur hara yang akan diserap tanaman semakin meningkat pula. Peningkatan penyerapan unsur hara akan maningkatkan pertumbuhan dan produksi tanaman.

Tabel 8. Hasil Analisis Bobot Polong Kering per Plot (g)

$\begin{array}{cc}\text { Perlakuan } & \begin{array}{c}\text { Bobot Polong Kering per Plot } \\ (\mathrm{g})\end{array}\end{array}$

\begin{tabular}{ll}
\hline Tandan kosong kelapa sawit (ton/ha) & \\
$\mathrm{t}_{0}: 0$ & $596,65 \mathrm{a}$ \\
$\mathrm{t}_{1}: 2$ & $612,09 \mathrm{a}$ \\
$\mathrm{t}_{2}: 4$ & $663,67 \mathrm{a}$ \\
$\mathrm{t}_{3}: 6$ & $744,36 \mathrm{~b}$ \\
Abu boiler (ton/ha) & \\
$\mathrm{b}_{0}: 0$ & $576,56 \mathrm{a}$ \\
$\mathrm{b}_{1}: 1$ & $611,06 \mathrm{a}$ \\
$\mathrm{b}_{2}: 2$ & $644,34 \mathrm{a}$ \\
$\mathrm{b}_{3}: 3$ & $784,81 \mathrm{~b}$ \\
\hline
\end{tabular}

Keterangan : Angka rata-rata pada setiap kolom yang ditandai dengan huruf yang sama menunjukkan tidak berbeda nyata menurut Uji Jarak Berganda Duncan pada taraf $5 \%$.

Hasil analisis ragam abu boiler terhadap bobot polong kering per plot menunjukkan berbeda nyata pada taraf perlakuan $b_{0}, b_{1}$, dan $b_{2}$ dibanding taraf perlakuan $b_{3}$. Hal ini sejalan dengan hasil bobot polong basah per plot. Hasil penelitian dari Ricki et al., (2013), menjelaskan bahwa abu boiler memiliki kandungan $30-40 \% \mathrm{~K}_{2} \mathrm{O}, 7 \% \mathrm{P}_{2} \mathrm{O}_{5}, 9 \% \mathrm{CaO}$ dan $3 \% \mathrm{MgO}$. Penambahan berbagai kandungan pupuk tersebut diduga menjadi faktor peningkatan produksi kacang tanah pada perlakuan 3 ton/ha.

\section{Jumlah Biji per Tanaman (buah)}

Hasil analisis ragam menunjukkan tidak terjadi interaksi antara berbagai dosis tandan kosong kelapa sawitdan dosis abu boiler kelapa sawit terhadap rata-rata jumlah biji per tanaman. Hal tersebut diduga karena faktor pupuk organik dengan kandungan unsur hara tinggi yang paling berpengaruh pada pertumbuhan tanaman.

Hasil analisis ragam kompos tandan kosong kelapa sawit terhadap jumlah biji per tanaman menunjukkan berbeda nyata pada taraf perlakuan $\mathrm{t}_{0}, \mathrm{t}_{1}$, dan $\mathrm{t}_{2}$ dibandingkan taraf perlakuan $t_{3}$. Hal ini sejalan dengan hasil analisis jumlah polong per tanaman. Hal tersebut diduga akibat dari lebih baiknya tesktur tanah akibat penambahan kompos, mikroorganisme yang menguntungkan dari kompos dan tambahan unsur hara dari kompos tandan kosong kelapa sawit membuat jumlah biji menjadi lebih banyak dibanding perlakuan yang lainnya salah satunya unsur hara $\mathrm{K}$. 
Tabel 9. Hasil Analisis Jumlah Biji per Tanaman (buah)

\begin{tabular}{lc}
\hline \multicolumn{1}{c}{ Perlakuan } & Jumlah Biji per Tanaman (buah) \\
\hline Tandan kosng kelapa sawit (ton/ha) & $35,73 \mathrm{a}$ \\
$\mathrm{t}_{0}: 0$ & $40,93 \mathrm{ab}$ \\
$\mathrm{t}_{1}: 2$ & $41,50 \mathrm{ab}$ \\
$\mathrm{t}_{2}: 4$ & $42,25 \mathrm{~b}$ \\
$\mathrm{t}_{3}: 6$ & \\
Abu boiler (ton/ha) & $36,88 \mathrm{a}$ \\
$\mathrm{b}_{0}: 0$ & $36,79 \mathrm{a}$ \\
$\mathrm{b}_{1}: 1$ & $39,65 \mathrm{a}$ \\
$\mathrm{b}_{2}: 2$ & $50,10 \mathrm{~b}$ \\
$\mathrm{~b}_{3}: 3$ & \\
\hline
\end{tabular}

Keterangan : Angka rata-rata pada setiap kolom yang ditandai dengan huruf yang sama menunjukkan tidak berbeda nyata menurut Uji Jarak Berganda Duncan pada taraf $5 \%$.

Tingkat ketersedian maupun serapan K yang tinggi sangat diperlukan. Kalium dapat berperan dalam memacu penyerapan air sebagai akibat hadirnya ion $\mathrm{K}^{+}$, sehinggga akan dapat memacu meningkatnya tekanan turgor sel yang mengakibatkan proses membuka dan menutupnya stomata. Membukanya stomata tersebut, akan memacu berlangsungnya proses asimilasi tanaman yang pada akhirnya akan berdampak pada banyaknya asimilat yang dihasilkan (Marschner, 2012). Asimilat yang dihasilkan pada tanaman kacang tanah kemudian disimpan pada komponen hasil yaitu biji kacang. Apabila asimilat lebih banyak menyebabkan jumlah biji menjadi lebih banyak juga.

Hasil analisis ragam abu boiler terhadap jumlah biji per tanaman terhadap jumlah biji per tanaman menunjukkan berbeda nyata pada taraf perlakuan $b_{0}, b_{1}$, dan $b_{2}$ dibandingkan taraf perlakuan $b_{3}$. Hal ini sejalan dengan hasil analisis ragam jumlah polong. Hal tersebut diduga karena pemberian abu boiler mempegaruhi $\mathrm{pH}$ tanah dan adanya penambahan unsur hara bagi tanaman sehingga memberikan peningkatan hasil yang berbeda nyata dibanding taraf perlakuan yang lain. Pada umumnya unsur hara akan mudah diserap tanaman pada $\mathrm{pH}$ 6-7, karena pada $\mathrm{pH}$ tersebut sebagian besar unsur hara akan mudah larut dalam air (Novizan, 2007).

\section{Bobot 100 Biji (g)}

Hasil analisis ragam menunjukkan tidak terjadi interaksi antara berbagai dosis tandan kosong kelapa sawitdan dosis abu boiler kelapa sawit terhadap rata-rata bobot 100 biji. Hal tersebut diduga karena faktor pupuk organik dengan kandungan unsur hara tinggi yang paling berpengaruh pada pertumbuhan tanaman.

Hasil analisis ragam kompos tandan tandan kosong kelapa sawit terhadap bobot 100 biji menunjukkan berbeda nyata pada taraf perlakuan $t_{0}, t_{1}$, dan $t_{2}$ dibanding taraf perlakuan $t_{3}$. Harjadi (1996), menyatakan bahwa tanaman akan tumbuh dengan baik apabila unsur hara yang dibutuhkan cukup tersedia dalam bentuk yang dapat diserap oleh tanaman. Selain itu peranan mikroorganisme dari kompos juga termasuk faktor penting dari peningkatan hasil kacang. Thabrani (2011) menyatakan bahwa bahan organik akan meningkatkan aktifitas biologi tanah dan kegiatan jasad mikro dalam membantu proses dekomposisi. Bahan organik 
yang terkandung didalam tandan kosong kelapa sawit dapat meningkatkan daya ikat air, serta memperbaiki aerase dan drainase tanah.

Tabel 10. Hasil Analisis Bobot 100 Biji (g)

\begin{tabular}{lc}
\multicolumn{1}{c}{ Perlakuan } & Bobot $100 \mathrm{Biji}(\mathrm{g})$ \\
\hline Tandan kosong kelapa sawit (ton/ha) & \\
$\mathrm{t}_{0}: 0$ & $29,54 \mathrm{a}$ \\
$\mathrm{t}_{1}: 2$ & $29,98 \mathrm{a}$ \\
$\mathrm{t}_{2}: 4$ & $31,52 \mathrm{ab}$ \\
$\mathrm{t}_{3}: 6$ & $33,04 \mathrm{~b}$ \\
Abu boiler (ton/ha) & \\
$\mathrm{b}_{0}: 0$ & $29,54 \mathrm{a}$ \\
$\mathrm{b}_{1}: 1$ & $29,94 \mathrm{a}$ \\
$\mathrm{b}_{2}: 2$ & $31,41 \mathrm{ab}$ \\
$\mathrm{b}_{3}: 3$ & $33,19 \mathrm{~b}$ \\
\hline $\mathrm{K}: 2$ & \\
\hline
\end{tabular}

Keterangan : Angka rata-rata pada setiap kolom yang ditandai dengan huruf yang sama menunjukkan tidak berbeda nyata menurut Uji Jarak Berganda Duncan pada taraf $5 \%$.

Hasil analisis ragam abu boiler terhadap bobot 100 biji menunjukkan berbeda nyata pada taraf perlakuan $b_{0}, b_{1}$, dan $b_{2}$ dibanding taraf perlakuan $b_{3}$. Menurut Brady (1989), perbaikan sifat kimia tanah terjadi berkat penambahan pupuk organik antara lain memperbesar kapasitas tukar kation tanah, meningkatkan kelarutan unsur fosfat dalam tanah, dan menyediakan unsur hara. Pupuk organik juga memperbaiki kondisi biologi tanah selain sifat fisik kimia bahkan secara tidak langsung kondisi fisika dan kimia tanah dipengaruhi oleh adanya aktivitas mikroorganisme.

\section{Kesimpulan}

Berdasarkan hasil penelitian dapat ditarik kesimpulan sebagai berikut :

1. Tidak terjadi interaksi antara dosis kompos tandan kosong kelapa sawit dan dosis abu boiler kelapa sawit terhadap pertumbuhan dan hasil tanaman kacang tanah.

2. Secara mandiri, dosis kompos tandan kosong kelapa sawit 6 ton/ha memberikan pengaruh terbaik terhadap bobot kering tanaman, bobot polong pertanaman, bobot polong basah per plot dan bobot polong kering per plot. Dosis abu boiler kelapa sawit pada taraf perlakuan 3 ton/ha memberikan pengaruh terbaik terhadap parameter pengamatan tinggi tanaman $45 \mathrm{HST}$, luas daun, jumlah daun 45 HST, bobot kering tanaman, jumlah polong per tanaman, bobot polong per tanaman, bobot polong basah per plot, bobot polong kering per plot, jumlah biji per tanaman, dan bobot 100 biji. 


\section{Daftar pustaka}

Agustina A.R., dan J. Purnomo. 2018. Hasil, Kualitas Fisik Polong dan Biji Beberapa Genotipe Kacang Tanah menurut Ragam Lengas Tanah pada Fase Generatif. Jurnal Agron.Indonesia, 46 (1): 71-80.

Anggoro, D. D. dan F. S. Budi. 2008. Proses Gliserolisis Minyak Kelapa Sawit Menjadi Mono dan Diacyl Gliserol dengan Pelarut N-Butanol dan Katalis MgO. Jurnal Reaktor, Vol 12(1): 22-28.

Astianto, A. 2012. Pemberian Berbagai Dosis Abu Boiler pada Pembibitan Kelapa Sawit (Elaeis guineensis Jacq) di Pembibitan Utama (Main Nursery). Skripsi. Fakultas Pertanian Universitas Riau.

Brady. 1989. Ilmu Tanah Terjemahan Soegiman. Bhatara Karya Aksara. Jakarta.

Direktorat Gizi. 2015. Komposisi Kimia Kacang Tanah. Direktorat Gizi Departemen Kesehatan RI, Jakarta.

Direktorat Jendral Perkebunan. 2017. Luas Lahan Kelapa Sawit Indonesia.http://www.ditjenbun.pertanian.go.id. Diakses tanggal $20 \mathrm{Mei}$ 2019.

Darnoko, D., Poelungan, Z. dan Anas, I., 1993. Pembuatan Pupuk Organik dari Tandan Kosong Kelapa Sawit. Buletin PPKS 1, 89-99.

Fitter A.H. dan Hay, R.K.M. 1991. Fisiologi Lingkungan Tanaman. Universitas Gajah Mada, Yokyakarta.

Hafner, H., B.J. Ndunguru, A. Bationo and H. Marschner. 1992. Effect of nitrogen, phosphorus and molybdenum application on growth and symbiotic N2fixation of groundnut in an acid sandy soil in Niger. Fert. Res. 31:69-77.

Halevy J. and A. Hartzook. 1988. Dry Matter Accumulation and Nutrient Uptake of HighYielding Peanut (Arachis Hypogaea L.) Grown in a Sandy Soil. Peanut Science. Abstract.15(1):5-8

Hannum, J., C. Hanum, dan J. Ginting. 2014. Kadar N, P Daun dan Produksi Kelapa Sawit Melalui Penempatan TKKS pada Rorak. Jurnal Online Agroekoteknologi, Vol 2(4): 1279-1286.

Hardjowigeno, S. 2004. Ilmu Tanah. Akademi Pressindo. Jakarta.

Hatta, M., Jafri, D. Permana. 2014. Pemanfaatan Tandan Kosong Sawit Untuk Pupuk Organik Pada Intercropping Kelapa Sawit Dan Jagung.Jurnal Pengkajian dan Pengembangan Teknologi Pertanian (JPPTP). Jalan Tentara Pelajar No. 10 Bogor, Indonesia.

Hayat, E. S. dan S. Andayani. 2014. Pengelolaan Limbah Tandan Kosong Kelapa Sawit dan Aplikasi Biomassa Chromolaena odorata terhadap Pertumbuhan dan Hasil Tanaman Padi Serta Sifat Tanah Sulfaquent. Jurnal Teknologi Pengelolaan Limbah (Journal Of Waste Management Technology), Vol 7 (2): 45-46.

Haryanti, A., Norsamsi, P.S.F. Sholiha dan N.P. Putri. 2014. Studi Pemanfaatan Limbah Padat Kelapa Sawit. Konversi 3 (2):20-29.

Harjadi, S.S. 1996. Pengantar Agronomi. Gramedia Pustaka Utama. Jakarta.

Hendra, H. A., Andoko, A. 2014. Bertanam Sayuran Hidroponik Ala Paktani Hydrofarm. Agro Media Pustaka. Jakarta. 
Inanaga, S., M. Utunomiya, T. Horiguchi, and T. Nishihara. 1990. Behaviour of fertilizer-N absorbed through root and fruit in peanut. Plant and Soil, 22 (1):85-89.

Ismunadji, M. 1989. Kalium: Kebutuhan dan penggunaannya dalam pertanian (terjemahan). PPI, Canada.

Junjittakarna, J., S. Pimratchb, S. Jogloya, W. Htoona, N. Singkhama, N. Vorasoot, B. Toomsana, C.C. Holbrookc, and A. Patanothai. 2013. Nutrient uptake of peanut genotypes under different water regimes. Inter. J. of Plant Prod. 7(4):677-692.

Kamil J. 1997. Teknologi Benih. Angkasa Raya. Padang.

Lingga, P. 1994. Petunjuk Penggunaan Pupuk. Penebar Swadaya. Jakarta.

Lingga, P. dan Marsono. 2003. Petunjuk Penggunaan Pupuk. Penerbit Swadaya. Jakarta.

Marschner, P. 2012. Mineral Nutrition of Higher Plants. London.

Meena S., M. Malarkodi and P. Senthilvalavan. 2007. Secondary and Micronutrients for Groundnut - A Review. Agric. Rev., 28(4):295-300.

Mengel, K. and E.A. Kirkby. 1987. Principles of Plant Nutrition. Edition 4. International Potash Institute. Switzerland.

Novizan. 2007. Petunjuk Pemupukan yang Efektif. PT Agro Media Pustaka. Jakarta.

Puguh F. K., H. Yetti., dan E. Anom. 2011. Peningkatan Produksi Kacang Hijau (Vigna radiata L.) dengan Pemberian Pupuk Kandang Ayam dan NPK. http://repository.unri.ac.id/bitstrea m/karya ilmiah/12345678/1789/1.pdf. Diakses pada Agustus 2020.

Purwaningsih, Ch. E. 2011. Pengaruh pemberian kompos blotong, legin, dan mikoriza terhadap serapan hara $\mathrm{N}$ dan $\mathrm{P}$ tanaman kacang tanah. Widya Warta, 02:55-68.

Rahmadi, R., A. Awaluddin, dan Itanawita. 2014. Pemanfaatan Limbah Padat Tandan Kosong Kelapa Sawit Dan Tanaman Pakis-Pakisan Untuk Produksi Kompos Menggunakan Aktivator EM-4. Jurnal Online Mahasiswa Fmipa, Vol 1(2): 245-253.

Rao, S. S and M. S. Shaktawat. 2005. Effect of organic manure, phosphorus and gypsum on nutrient uptake in groundnut. Agropedology, 15(2):100-106.

Resh, H, M. 2013. Hobby Hidroponics. 2nd Edition. CRC Press. Inc.

Reza M, E. Widaryanto dan H.T. Sebayang. 2017. Pengaruh Waktu Pengendalian Gulma terhadap Pertumbuhan dan Hasil Tanaman Kacang Hijau (Vigna radiata L.) pada Berbagai Taraf Pemupukan Nitrogen. Jurnal Produksi Tanaman, Vol. 5(4): 616 - 624.

Sudaryani, T dan E Sugiharti. 1990. Budidaya Dan Penyulingan Nilam. PT Penebar Swadaya. Jakarta.

Syafril, H.E., dan Andayani, S. 2014. Pengelolaan Limbah Tandan Kosong Kelapa Sawit Dan Aplikasi Biomassa Chromolaena Odorata Terhadap Pertumbuhan Dan Hasil Tanaman Padi Serta Sifat Tanah Sulfaquent. Jurnal Teknologi Pengelolaan Limbah (Journal of Waste Management Technology), ISSN 1410-9565. Pusat Teknologi Limbah Radioaktif (Center for Radioactive Waste Technology).

Sutedjo, M. 2006. Pupuk dan Cara Pemukan. Rineka Cipta. Jakarta. 
Thabrani, A. 2011. Pemanfaatan kompos ampas tahu untuk pertumbuhan bibit kelapa sawit (Elaeis guineensis Jacq).Skripsi Fakultas Pertanian Universitas Riau. Pekanbaru.

Tim Bina Karya Tani. 2009. Pedoman Bertanam Kacang Tanah. Yrama Widya. Bandung.

Trustinah. 2015. Pertumbuhan Kacang Tanah. Monograf Balitkabi. Balai Penelitian Tanaman Aneka Kacang dan Umbi.http://balitkabi.litbang.pertanian.go.id/wpcontent/uploads/2015/06/ 4._OK_Trustinah_Morfo_40-59-1.pdf. Diakses tanggal 18 Oktober 2019.

Wiekandyne, D. 2012. Pengaruh Pupuk Urea, Pupuk Organik Padat dan Cair Kotoran Ayam terhadap Sifat Tanah, Pertumbuhan dan Hasil Selada Keriting di Tanah Inseptisol. Jurnal Sains Mahasiswa Agroteknologi, 4(1): 236-246. 